\title{
DESIGN AND CONSTRUCTION PROBLEMS CONNECTED WITH ENSURING EVEN THERMAL INSULATION OF SINGLE-LAYER WALLS
}

\author{
Bohdan STAWISKI ${ }^{1}$ \\ Wroclaw University of Technology, Faculty of Civil Engineering, \\ Wroclaw, Poland
}

\begin{abstract}
The design of single-layer walls appears to be extremely simple. In the opinion of many designers, the additional insulation of tie beams and balconies continues to solve all problems. However, tests on single-layer walls show that the expressed opinion is not valid. The study quotes the results of tests on single-layer walls with strong signs of freezing. The conducted analysis of the design solution and calculation of the fRsi temperature factor on the internal surface and its comparison with fRsi determined empirically enabled reasons behind failure in the construction of the tested walls to be identified. The study presents problems connected with ensuring uniformity of the temperature field in walls, possibilities for detecting areas susceptible to the development of mold, and protection of partitions from the occurrence of this phenomenon by performing appropriate repair works preceding necessary renovations of the building which takes place after the occurrence of mold on walls and ceilings.
\end{abstract}

Keywords: single-layer walls, thermal protection, thermal bridges, detection

\section{INTRODUCTION}

Single-layer walls are the oldest type of wall applied in construction. However, for years they made up primarily the load-bearing construction of the building. Temperature and humidity requirements did not begin to take on greater importance until the past century. Masonry elements had to change thermal

\footnotetext{
${ }^{1}$ Corresponding author: Wroclaw University of Technology, Faculty of Civil Engineering, Wybrzeże Wyspiańskiego 27, 50-370 Wroclaw, Poland, e-mail: bohdan.stawiski@pwr.edu.pl, tel. +48713203928
} 
resistance as requirements became stricter; this continues to take place to this day, with acceptable heat loss from buildings being further reduced. In Poland, the most recent regulations date from the end of 2013 [1]. As of January 2014, the acceptable heat-transfer coefficient for external walls is $\mathrm{U} \leq 0.25 \mathrm{~W} / \mathrm{m}^{2} \mathrm{~K}$; starting in 2017 , the permissible value will be $U \leq 0.23 \mathrm{~W} / \mathrm{m}^{2} \mathrm{~K}$, while the permissible value for 2021 has been set at $U \leq 0.2 \mathrm{~W} / \mathrm{m}^{2} \mathrm{~K}$. For flat roofs, those values are $\mathrm{U} \leq 0.2 ; 0.18$ and $0.15 \mathrm{~W} / \mathrm{m}^{2} \mathrm{~K}$, respectively.

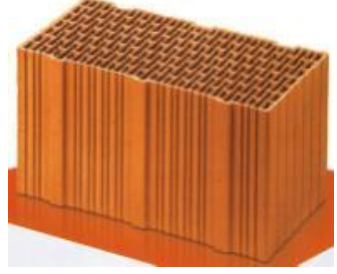

a)

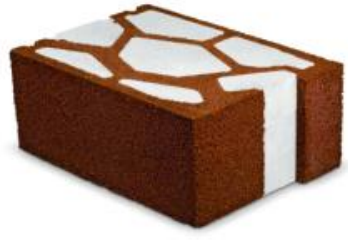

b)

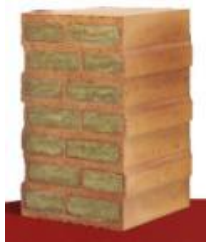

c)

Fig. 1. Examples of masonry elements with a high diffusion resistance without filler and filled with a thermal insulation material: a) cinder block of porous ceramics with many openings, b) light expanded clay aggregate (LECA) block, filled with styrofoam,

c) ceramic block filled with mineral wool

The tendency to reduce energy losses through walls has been observed for years and has inspired the manufacturers of building materials to offer increasingly better masonry materials in terms of thermal insulation. From the perspective of time, a clear direction of the introduced changes can be observed; the porosity of bricks, concrete and aggregates has been increased, foamed and aerated concrete have been created, and cinder blocks have been developed simultaneously. The first ones met the requirements by a few large openings; next, the number of openings within the thickness of the wall was increased, currently resulting in over thirty holes (Fig. 1a). The newest cinder blocks have openings filled with good insulation material, such as styrofoam or mineral wool (Fig. 1b, 1c), thanks to which the thermal resistance of these products has greatly improved. It is still possible to construct single-layer external walls.

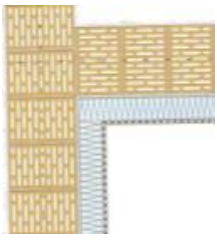

a)

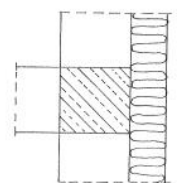

b)

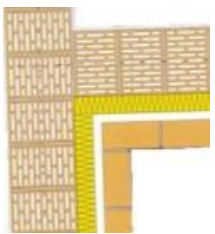

c)

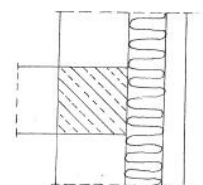

d)

Fig. 2. Thermal insulation in double- and triple-layer walls; a) and c) lack of thermal bridges, b) and d) insignificant thermal bridges on the tie beams of reinforced concrete walls and ceilings 
In double- and triple-layer walls, when a continuous and thick-layer of thermal insulation (with high thermal resistance) is ensured, thermal bridges e.g., on tie beams, have little influence on lowering the temperature of the surface of the wall $\Theta_{\mathrm{si}}$ in their area (Fig. 2), contrary to single-layer walls.

\section{THERMAL BRIDGES IN SINGLE-LAYER WALLS}

In single-layer walls, floors are supported by part of the wall, as there is the necessity of insulating the tie-beam; however, this unfortunately does not completely eliminate thermal bridges (Fig. 3). This is particularly dangerous when the thermal insulation is thin (poor) due to being hidden under the façade (Fig. 3a).
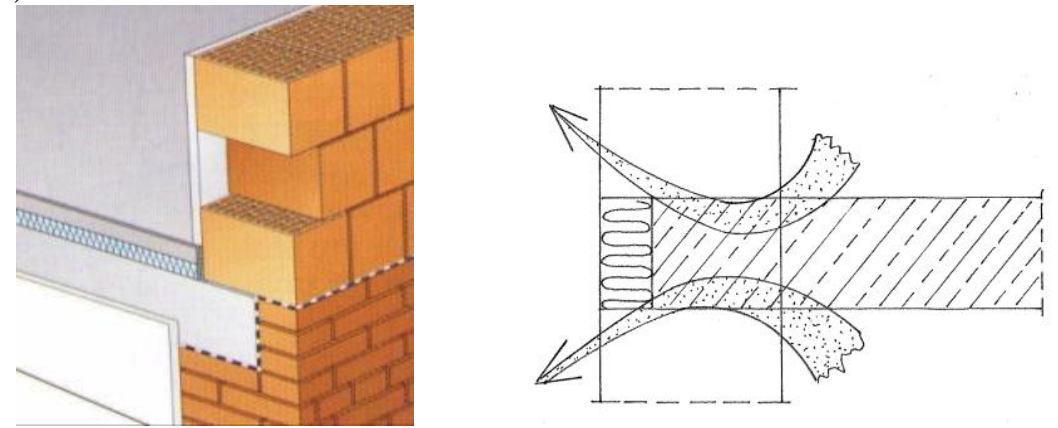

Fig. 3. Thermal bridges in a single-layer wall with a poorly insulated reinforced concrete tie beam

In solutions with balconies, thermal bridges are especially frequent (Fig. 4).
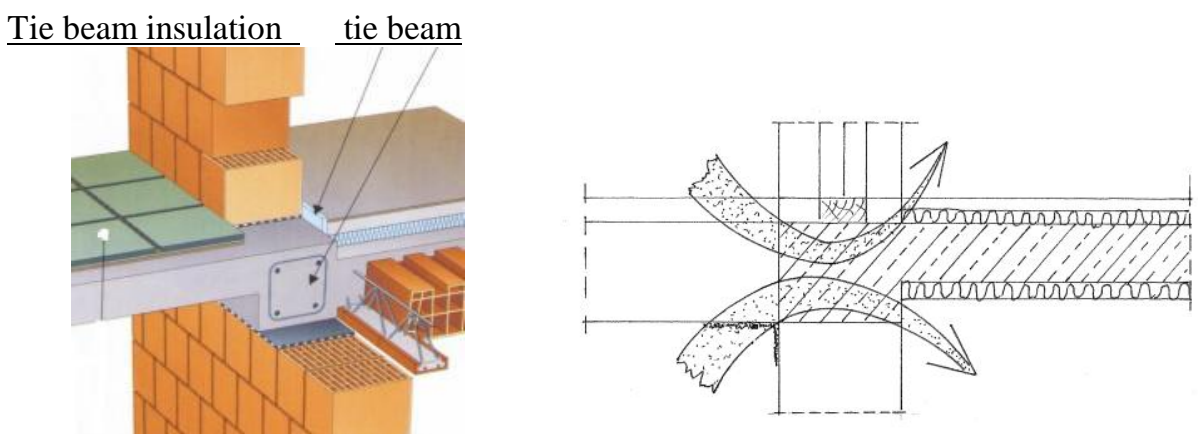

Fig. 4. Thermal bridges at the connection of the floor with a cantilevered balcony. The corners where the floor-wall meets lose heat (freezing effect - the occurrence of mold and mildew) 


\section{CASE STUDY OF BUILDINGS WITH SINGLE-LAYER WALLS}

The study encompassed a two-storey building without a basement, with a usable attic built in 2010. The walls were designed and constructed as single-layer walls from light expanded clay aggregate (LECA) blocks, $365 \mathrm{~mm}$ in thickness and plastered on both sides. The heat transfer coefficient was calculated as $\mathrm{U}=0.38 \mathrm{~W} / \mathrm{m}^{2} \mathrm{~K}$. The southern wall was all glass, with access to a balcony upstairs and a terrace on the ground floor. The concrete slab of the terrace as well as the reinforced concrete balcony made were connected with the floors in the project, without providing a detailed solution as to thermal protection. The description only called for insulating the balcony and terrace from the top, and additionally the balcony from the bottom using $3 \mathrm{~cm}$ thick styrofoam. After the first year that the building was in use, the wall and ceiling corner underneath the balcony and above the terrace became covered with a coating of mold (Fig. 5)

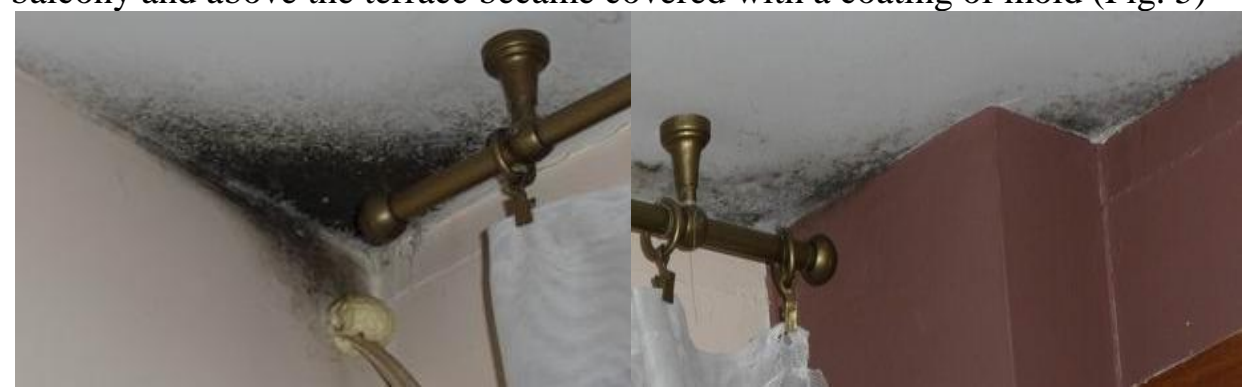

Fig. 5. Mold-covered upper wall corner below the balcony and ceiling comprising an extension of the balcony

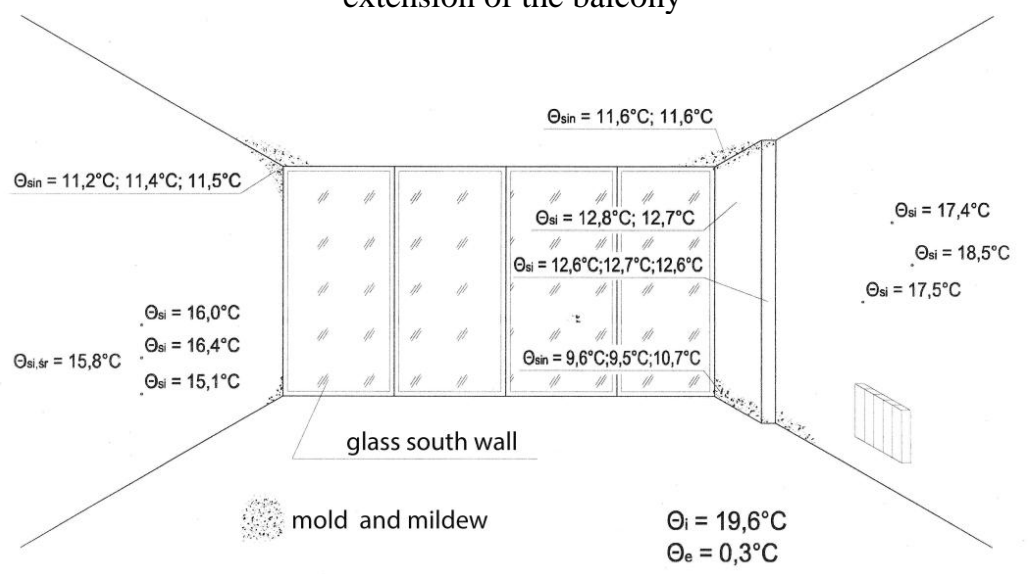

Fig. 6. Air temperature $\Theta_{\mathrm{i}}$ and wall surface temperature $\Theta_{\mathrm{si}}$ are at the expected level. In the corners, the temperature $\Theta_{\sin }$ is a few degrees lower. Residues of mold appear in these areas 
Looking for reasons behind the existing state, the following measurements were taken: temperature of the wall surfaces with a spot temperature sensor and next, using thermovision, and the moisture content of the air and walls. The results of the measurements of the temperature of the wall surfaces using a spot temperature sensor have been shown in Fig. 6.

The maximum difference in the temperature between the surface of the wall located far from the corner and temperature in the corner is very high $\Delta \mathrm{t}_{\max }=\Theta_{\mathrm{si}^{-}}$ $\Theta_{\sin }=16.4-9.5=6.9^{\circ} \mathrm{C}$. The average difference in the temperatures of the walls is $\Delta \mathrm{t}_{\text {przec }}=16.0-12.6=3.4^{0} \mathrm{C}$, whereas of the walls and ceiling $\Delta \mathrm{t}_{\text {przec }}=16.0$ $11.4=4.6^{\circ} \mathrm{C}$. Such obvious temperature differentiation confirms the existence of thermal bridges discussed in part 2 [2].

In order to determine the actual heat transfer coefficient for the wall of LECA blocks, measurements of heat flux density $q_{i}$ were taken in areas distant from the corners, with the difference in the temperature on both sides of the wall $\Delta \mathrm{t}=16.9^{\circ} \mathrm{C}$. The average value of the heat transfer coefficient was calculated from the equation

$$
U_{a r}=\frac{1}{6} \sum_{1}^{6} \frac{q_{i}^{i}}{\theta_{\mathrm{i}}-\theta_{e}}=0,34 \mathrm{~W} / \mathrm{m}^{2} \mathrm{~K}
$$

The obtained value only slightly exceeded the requirements in effect at the time the building was constructed. The quick development of mold in the corners suggested another reason in addition to thermal bridges - the lack of effective ventilation. Measurement of the speed of air flow in the kitchen and bathroom ventilation ducts using a vane anemometer revealed it to have stopped completely with closed windows and doors $(0 \mathrm{~m} / \mathrm{s})$, while with windows and inside doors left ajar, air flows of $0.3 \mathrm{~m} / \mathrm{s}$ in the bathroom and $0.6 \mathrm{~m} / \mathrm{s}$ in the kitchen connected with the living room were registered. The minimal speed of air flow in typical ventilation ducts is considered to be $0.6-0.9 \mathrm{~m} / \mathrm{s}$ [3].

In the analyzed house, the reason behind the ineffective ventilation were airtight windows lacking trickle vents. The system of unsealing windows is never sufficient, as when ventilation is most needed, that is when outside temperatures are low, venting the windows leads to uncontrolled cooling of the building and is not practiced by the dwellers [4]. The conducted instrumental studies confirmed good thermal parameters of single-layer walls with the exception of the corners in the area of the balcony and terrace slabs. Such flaws can now be easily diagnosed, even before mold appears on the partitions. 


\section{ESTIMATING THE RISK OF THE DEVELOPMENT OF MOLD ON PARTITIONS}

The norm PN-EN ISO 13788 [5] makes it possible to assess the risk of water vapor condensation of the surface of a partition and the development of mold and mildew [6,7]. Calculations of the minimum temperature factor on the inside surface of a single-layer wall made of LECA blocks, $365 \mathrm{~mm}$ in thickness and plastered on both sides with cement-lime plaster $15 \mathrm{~mm}$ in thickness were carried out. The thermal resistance of the wall was found to be $\mathrm{R}=2.66 \mathrm{~m}^{2} \mathrm{~K} / \mathrm{W}$, the heat transfer coefficient $\mathrm{U}=0.376 \mathrm{~W} / \mathrm{m}^{2} \mathrm{~K}$. The average outside temperatures $\Theta_{\mathrm{e}}$ in Wrockaw for the months from January to December were accepted as: $2.0,1.2 ; 3.5 ; 7.7 ; 10.7,15.5,18.7,16.3,14.5,8,7,4.0,1.9^{0} \mathrm{C}$. The effective value of the temperature factor:

$$
f_{\text {Rsi }}=\frac{U^{-1}-R_{\text {Si }}}{U^{-1}}=0,937
$$

The value of the minimum temperature factor $\mathrm{f}_{\text {Rsi,min }}$ was calculated for all months. For the critical month, which turned out to be January, $\mathrm{f}_{\mathrm{Rsi}, \max }=0.907$. The following condition in fulfilled:

$$
f_{\text {Rsi }}=0.937>f_{\text {Rsi,max }}=\max \left(f_{\text {Rsi,min }}\right)=0.907
$$

The analyzed partition is designed correctly in terms of avoiding the development of mold.

The above calculations pertain to a wall outside of thermal bridges, which may exist due to mistakes made during the design or construction process. If the $\Theta_{\mathrm{i}}$, $\Theta_{\mathrm{si}}$ and $\Theta_{\mathrm{e}}$ temperature is measured in areas suspected of the presence of thermal bridges (most often corners, lintels, sprandels), then the temperature factor $\mathrm{f}_{\mathrm{Rsi}}$ can be calculated form the following formula:

$$
f_{R s i}=\frac{\theta_{s i}-\theta_{e}}{\theta_{i}-\theta_{\theta}}
$$

where: $\Theta_{\mathrm{i}}$ and $\Theta_{\mathrm{e}}$ - temperature inside and outside of a room,

$\Theta_{\mathrm{si}}$ - temperature on the surface of the expected thermal bridge, e.g. based on thermographic studies.

In the analyzed building, in the corner of the room, the following was determined:

$$
f_{\text {Rsi }}=\frac{11.2-3.0}{19.6-3.0}=0.494<f_{\text {Rsi,max }}=0.907
$$

Meaning that the mold and mildew will develop in that corner, where it in fact had (Fig. 5, 6). 


\section{CONCLUSIONS}

The assessed single-layer walls made of LECA blocks fulfilled the designer's expectations in terms of thermal insulation at the accepted temperature and humidity parameters. The connection between the balcony slab and the floor created such strong thermal bridges that the development of mold and mildew was inevitable in rooms of the class 4 moisture category.

The obligatory assessment of partitions in terms of the presence of thermal bridges by carrying out thermographs or taking temperature measurements on the surface of walls with a simple spot temperature sensor would make it possible to carry out repairs on the wall prior to inhabiting the building. The advantage of the described control method is that the assessment is made without damaging the partition; a disadvantage is the necessity of creating a given heat flow though the partition, meaning a difference of a few dozen degrees between the two sides of the partition.

\section{REFERENCES}

1. Warunki techniczne, jakim powinny odpowiadać budynki i ich usytuowanie. Rozporządzenie Ministra Infrastruktury z 12 kwietnia 2002 r. (Dz.U. z 2002 r., nr 75, poz. 690 z późniejszymi zmianami). Tekst ujednolicony, Murator $1 / 2014$.

2. FOKIN K. F.: Stroitelnaja teplotechnika ograzdajuschich castej zdanij. Strojizdat, Moskwa 1954.

3. NOCKO K.: Wentylacja $w$ budynkach mieszkalnych - wymagania $i$ zagrożenia. IV Warsztaty mykologiczno - budowlane. PSMB, Wrocław Huta Szklana 2002.

4. STAWISKI B.: Nowoczesna stolarka budowlana a fizyka i mykologia budowy. III Warsztaty Mykoloogiczno - budowlane. PSMB, Wrocław Huta Szklana 2002.

5. PN-EN ISO 13788 Cieplno - wilgotnościowe właściwości komponentów budowlanych i elementów budynku.

6. MARSZAŁEK K., NOWAK H.: Analiza wplywu mostków cieplnych przegród budowlanych na rozwój grzybów pleśniowych. III Sympozjum PSMB „Ochrona obiektów budowlanych przed korozją biologiczną i ogniem”, Szklarska Poręba 1995.

7. MARSZAŁEK K.: Przestrzenny rozktad dla obszaru Polski wartości czynnika temperaturowego $w$ aspekcie ochrony przegród budowlanych przed rozwojem pleśni. PSMB, Wrocław, Prace Naukowe, Monografie nr $7 / 2011$. 


\title{
KONSTTRUKCYJNE I WYKONAWCZE PROBLEMY ZWIAZZANE Z ZAPEWNIENIEM RÓWNOMIERNEJ IZOLACYJNOŚCI TERMICZNEJ ŚCIAN JEDNOWARSTWOWYCH
}

\begin{abstract}
Streszczenie
Projektowanie ścian jednowarstwowych wydaje się wyjątkowo proste. Dodatkowe ocieplenie wieńców i balkonów, w opinii wielu projektantów rozwiązuje wszystkie problemy. Jednak badania ścian jednowarstwowych pokazują, że wyrażona opinia nie jest prawdziwa. W referacie przytoczono wyniki badania ścian jednowarstwowych z silnymi oznakami przemarzania. Przeprowadzona analiza rozwiązania projektowanego oraz obliczenie czynnika temperatury $\mathrm{f}_{\mathrm{Rsi}}$ na wewnętrznej powierzchni i porównanie go $\mathrm{z} \mathrm{f}_{\mathrm{Rsi}}$ wyznaczonym empirycznie pozwoliło wskazać przyczyny niepowodzenia $\mathrm{W}$ realizacji badanej ściany. Pokazano problemy związane z zapewnieniem jednorodności pola temperaturowego w ścianach oraz możliwości wykrywania obszarów podatnych na prawdopodobny rozwój pleśni i ochronę przegród przed zaistnieniem tego zjawiska przez wykonanie odpowiednich prac naprawczych poprzedzających niezbędny remont budynku po zagrzybieniu ścian i stropów.
\end{abstract}

Słowa kluczowe: ściany jednowarstwowe, ochrona cieplna, mostki termiczne, wykrywanie

Editor received the manuscript: 28.01.2015 